\title{
PENGEMBANGAN MEDIA PEMBELAJARAN KONSEP LUAS BIDANG DATAR BERBASIS PERANGKAT LUNAK GEOGEBRA
}

\author{
Sendi Ramdhani \\ FKIP Universitas Suryakancana Cianjur \\ sendiramdhani@yahoo.com, sendi@unsur.ac.id
}

\begin{abstract}
This study aims to produce GeoGebra-based learning media of plane area concept that is valid, practical, and has good potential effects. This research use development research method or development research of formative research type which is simplified. Learning media development procedure in this research consists of 3 stages: 1) self evaluation, 2) prototyping (validation, evaluation and revision), 3) Field test. The results of research can be explained that: 1) the development of GeoGebra-based learning media of plane area concept in MTs Kab. Bandung valid based on contents, language, and conformity of context used and practical based on ease of use of students, 2) trials result of development of GeoGebra-based learning media of plane area concept given in MTs Kab. Bandung has a potential effect, namely: students love to learn with computer media, students love to learn with GeoGebra software, GeoGebra-based learning media of plane area concept helps students understand the area concept, learning media of area rectangular is most helpful to students understand the area concept.

Keywords: learning media, GeoGebra, area, plane
\end{abstract}

\begin{abstract}
Abstrak
Penelitian ini bertujuan untuk menghasilkan media pembelajaran konsep luas bidang datar berbasis perangkat lunak geogebra yang valid, praktis, dan mempunyai potensi efek yang baik. Penelitian ini menggunakan metode penelitian pengembangan atau development research tipe formative research yang disederhanakan.Prosedur pengembangan media pembelajaran dalam penelitian ini terdiri dari 3 tahapan yaitu: 1) evaluasi diri, 2) prototyping (validasi, evaluasi dan revisi ), 3) Uji lapangan. Hasil penelitian dapat dipaparkan bahwa: 1) hasil pengembangan media pembelajaram konsep luas bidang datar berbasis perangkat lunak Geogebra di MTs Kab. Bandung valid berdasarkan isi, bahasa, dan kesesuaian konteks yang digunakan dan praktis berdasarkan kemudahan digunakan siswa, 2) hasil uji coba pengembangan media pembelajaran konsep luas bidang datar berbasis perangkat lunak Geogebra yang diberikan di MTs Kab. Bandung mempunyai efek yang potensial, yaitu: siswa suka belajar dengan media komputer, siswa suka belajar dengan perangkat lunak Geogebra, media pembelajaran konsep luas bidang datar berbasis perangkat lunak Geogebra membantu siswa memahami konsep luas, media pembelajaran luas persegi panjang paling membantu siswa memahami konsep luas.
\end{abstract}

Kata kunci : media pembelajaran, geogebra, luas, bidang datar 


\section{PENDAHULUAN}

Media pembelajaran adalah media yang menyajikan pesan-pesan terkait dengan tujuan pembelajaran. Media bagian penting dalam pembelajaran matematika karena merupakan komponen sumber belajar atau wahana fisik yang mengandung materi instruksional di lingkungan siswa yang dapat menarik perhatian siswa untuk belajar. Media penting dalam pembelajaran matematika karena 1) objek matematika abstrak sehingga butuh peragaan; 2) Sifat materi matematika yang tidak mudah dipahami; 3) Hirarki matematika ketat dan kaku; 4) Aplikasi matematika kurang nyata; 5) Belajar matematika perlu fokus; 6) Citra pembelajaran matematika kurang baik; 7) Kemampuan kognitif siswa masih konkret; 7) Motivasi belajar siswa masih rendah (Kementerian Pendidikan dan Kebudayaan RI, 2014).

Leshin, Pollock \& Reigeluth (1992) mengklasifikasi media ke dalam lima kelompok, yaitu: 1) Media berbasis manusia; 2) Media berbasis cetak; 3) Media berbasis visual 4) Media berbasis audio-visual; 5) Media berbasis komputer. Media pembelajaran berbasis komputer memiliki beberapa kelebihan antara lain dapat meningkatkan dan memperluas pembelajaran yang memungkinkan siswa merancang eksplorasinya sendiri dan menyusun pengetahuan atau ide sendiri. Penggunaan teknologi seperti media interaktif pembelajaran matematika akan membuat matematika yang konsep-konsepnya abstrak menjadi lebih nyata karena bisa ditampilkan dalam bentuk visualisasi. Bagi para siswa, visualisasi akan lebih menyenangkan dan memudahkan dalam pembelajaran matematika (Ramdhani, 2016).

Salah satu perangkat lunak komputer yang dapat dimanfaatkan dalam pembelajaran matematika adalah perangkat lunak GeoGebra. Dengan beragam fasiltas yang dimiliki, GeoGebra dapat dimanfaatkan sebagai media pembelajaran matematika untuk mendemonstrasikan atau memvisualisasikan konsep-konsep matematis serta sebagai alat bantu untuk mengkonstruksi konsep-konsep matematis (Mahmudi, 2011).

GeoGebra dikembangkan oleh Markus Hohenwarter pada tahun 2001.GeoGebra adalah perangkat lunak matematika gratis dan multiplatform yang dinamis untuk semua tingkat pendidikan yang menggabungkan geometri, aljabar, tabel, grafik, statistik dan kalkulus dalam satu paket yng mudah digunakan. Perangkat lunak ini telah menerima beberapa penghargaan perangkat lunak pendidikan di Eropa dan Amerika Serikat. Beberapa kelebihan GeoGebra antara lain : 1) grafik, aljabar dan tabel terhubung dan sangat dinamis; 2) Mudah digunakan namun banyak fitur canggih, 3) authoring tool (alat pengubah) untuk membuat bahan pembelajaran interaktif sebagai halaman web; 4) tersedia dalam banyak bahasa untuk jutaan pengguna kami di seluruh dunia; dan 5) Perangkat lunak open source 
yang tersedia secara bebas untuk pengguna non-komersial (GeoGebra, n.d.).

Materi luas bidang datar merupakan materi yang membutuhkan peragaan dan terdapat hirarki materi matematika sehingga membutuhkan media dalam proses pembelajarannya. Media berbasis komputer memvisualisasikan bidang datar sehingga memudahkan dan lebih menyenangkan bagi para siswa. GeoGebra yang merupakan singkatan dari Geometry dan Algebra memuat fasilitas Geometri dan Aljabar sehingga bisa menggabungkan visualisasi bidang datar beserta ekplorasi rumus luasnya. Bahan pembelajaran interaktif juga dapat dibuat melalui GeoGebra.

Dalam penelitian ini dikembangkan media pembelajaran konsep luas bidang datar berbasis perangkat lunak geogebra yang valid, praktis, dan mempunyai potensi efek yang baik. Konsep luas bidang datar yang akan dikembangkan adalah persegi panjang, segitiga, jajargejang, layang-layang, trapesium, dan lingkaran.

\section{Pedoman Pengembangan Media Pembelajaran Berbasis Perangkat Lunak Geogebra}

Pedoman pengembangan

media pembelajaran berbasis perangkat lunak geogebra berdasarkan pada prinsip-prinsip desain untuk multimedia pembelajaran dinyatakan oleh Clark dan Mayer (Hohenwarter dan Hohenwarter, 2013). Pedoman pengembangan ini dibagi kedalam tiga bagian, yaitu: 1) Pedoman Desain Media Pembelajaran Dinamis; 2) Pedoman Desain Gambar Dinamis; dan 3) Pedoman Desain Penjelasan dan Tugas.

Beberapa hal yang harus diperhatikan dalam mendesain media pembelajaran berbasis perangkat lunak GeoGebra antara lain: 1) menghindari scrolling artinya seluruh muat di satu layar; 2) memuat penjelasan singkat yang memuat satu atau dua kalimat; 3) memuat tugas untuk memastikan siswa menggunakan dengan aktif; 4) berisi objek-objek yang relevan dengan tujuan pembelajaran.

Berkaitan dengan desain gambar dinamis yang harus diperhatikan yaitu gambar harus interaktif dimana gambar bergerak atau berubah harus menyediakan kebebasan untuk eksplorasi sehingga siswa menemukan hubungan objek matematika dan menemukan konsepkonsep matematika. Gambar dinamis harus mudah digunakan dalam arti mudah dipindahkan atau diubah, terdapat perbedaan warna dan ukuran untuk memudahkan memahami petunjuk-petunjuk, dan tidak dapat dipindahkan tanpa ketidaksengajaan. Gambar harus cukup besar untuk memungkinkan semua manipulasi tetapi cukup kecil untuk muat di satu layar dan masih meninggalkan ruang yang cukup untuk penjelasan dan pertanyaan.

Adapun dalam penjelasan dan tugas harus singkat, jelas, dan komunikatif. Pertanyaan harus spesifik, misalnya“Apa yang terjadi pada $\mathrm{X}$ 
ketika Anda pindahkan Y?".Jumlah pertanyaan tiga atau empat pertanyaan. Namun pertanyaan harus dihindari jika media pembelajaran dimaksudkan untuk presentasi atau demontrasi.

\section{KAJIAN TEORI}

\section{Pedoman Pengembangan Media} Pembelajaran Berbasis Perangkat Lunak Geogebra

Pedoman pengembangan

media pembelajaran berbasis perangkat lunak geogebra berdasarkan pada prinsip-prinsip desain untuk multimedia pembelajaran dinyatakan oleh Clark dan Mayer (Hohenwarter dan Hohenwarter, 2013). Pedoman pengembangan ini dibagi kedalam tiga bagian, yaitu: 1) Pedoman Desain Media Pembelajaran Dinamis; 2) Pedoman Desain Gambar Dinamis; dan 3) Pedoman Desain Penjelasan dan Tugas.

Beberapa hal yang harus diperhatikan dalam mendesain media pembelajaran berbasis perangkat lunak GeoGebra antara lain: 1) menghindari scrolling artinya seluruh muat di satu layar; 2) memuat penjelasan singkat yang memuat satu atau dua kalimat; 3) memuat tugas untuk memastikan siswa menggunakan dengan aktif; 4) berisi objek-objek yang relevan dengan tujuan pembelajaran.

Berkaitan dengan desain gambar dinamis yang harus diperhatikan yaitu gambar harus interaktif dimana gambar bergerak atau berubah harus menyediakan kebebasan untuk eksplorasi sehingga siswa menemukan hubungan objek matematika dan menemukan konsepkonsep matematika. Gambar dinamis harus mudah digunakan dalam arti mudah dipindahkan atau diubah, terdapat perbedaan warna dan ukuran untuk memudahkan memahami petunjuk-petunjuk, dan tidak dapat dipindahkan tanpa ketidaksengajaan. Gambar harus cukup besar untuk memungkinkan semua manipulasi tetapi cukup kecil untuk muat di satu layar dan masih meninggalkan ruang yang cukup untuk penjelasan dan pertanyaan.

Adapun dalam penjelasan dan tugas harus singkat, jelas, dan komunikatif. Pertanyaan harus spesifik, misalnya“"Apa yang terjadi pada $X$ ketika Anda pindahkan Y?".Jumlah pertanyaan tiga atau empat pertanyaan. Namun pertanyaan harus dihindari jika media pembelajaran dimaksudkan untuk presentasi atau demontrasi.

\section{METODE PENELITIAN}

Penelitian ini menggunakan metode penelitian pengembangan atau development research tipe formative research yang disederhanakan. Adapun yang dikembangkan dalam penelitian ini adalah perangkat pembelajaran yang berupa media pembelajaran konsep luas bidang datar berbasis perangkat lunak GeoGeobra. Penelitian ini dilaksanakan pada semester ganjil tahun ajaran 2016/ 2017. Subjek dalam penelitian ini berjumlah 33 siswa yang berasal dari kelas VII di MTs Al Basyariyah Kab. Bandung. 


\section{Prosedur Pengembangan}

Prosedur pengembangan media pembelajarandalampenelitianiniterdiri dari 3 tahapan yaitu: 1) Evaluasi Diri; 2) Prototyping (validasi, evaluasi dan revisi); 3) Uji Lapangan (Nizarwati, Hartono, \& Aisyah, 2009).

Pada tahap evaluasi diri terdiri dari analisis dan desain. Tahap analisis ini merupakan langkah awal penelitian pengembangan. Peneliti dalam hal ini menganalisis siswa, analisis kurikulum dan analisis materi sesuai dengan KTSP MTs Al Basyariyah Kab. Bandung. Adapun desain media pembelajaran yang dibuat, meliputi: 1) Luas Persegi Panjang; 2) Luas Segitiga; 3) Luas Jajargenjang; 4) Luas Layang-layang; 5) Luas Trapesium; 6) Luas Lingkaran

Tahap Prototyping (Validasi, Evaluasidan Revisi) merupakan tahapan Practitioner Review atau reviu dari praktisi. Hasil desain pada prototype pertama yang dikembangkan atas dasar evaluasi diri diberikan pada praktisi (Practitioner review) untuk menelaah isi, konsep, petunjuk, bahasa, gambar, dan animasi. Praktisi adalah tiga orang guru matematika SMP/ MTs. Saran-saran digunakan untuk merevisi desain media pembelajaran.Saran dan masukan dari praktisi dijadikan bahan revisi dan menjadi prototipe kedua.

Selanjutnnya tahap uji lapangan yaitu hasil revisi diujicobakan ke subjek penelitian ada tahap ini produk yang telah direvisi diujicobakan kepada siswa kelas VII MTs Al Basyariyah yang menjadi subjek penelitian.Produk yang diujicobakan telah memenuhi standar validitas, kepraktisan dan keefektifan.

\section{Metode Pengumpulan Data}

Metode pengumpulan data yang dipakai dalam penelitian ini adalah angket yang digunakan untuk memperoleh data tentang respon siswa terhadap media pembelajaran konsep luas bidang datar berbasis perangkat lunak GeoGebra.

\section{Teknik Analisi Data}

Teknik analisis data yang digunakan dalam penelitian ini adalah analisis deskriptif kualitatif.Uraian singkat tentang teknik analisis beserta kriteria yang menjadi acuan hasil analisis masing-masing jenis data sebagai berikut :

\section{Analisis Data dari Validasi Praktisi \\ Analisis yang digunakan} adalah analisis deskriptif dengan cara merevisi berdasarkan catatan validator yang ditinjau dari 3 karakteristik yaitu isi, konsep, petunjuk, bahasa, gambar, dan animasi. Hasil analisis akan digunakan untuk merevisi media pembelajaran.

2. Analisis data angketsiswa.

Analisis data angket siswa untuk mengetahui respon siswa terhadap proses media pembelajaran konsep luas bidang datar berbasis perangkat lunak GeoGebra. Analisis data angket siswa juga untukmengetahui bahan ajar mana yang paling membantu siswa memahami konsep luas dan bahan ajar mana yang paling sulit dipahami siswa. 
HASIL PENELITIAN DAN PEMBAHASAN

Pada tahap prototyping, diadakan persiapan analisis kurikulum matematika, berdasarkan Kurikulum Tingkat Satuan Pendidikan (KTSP) pada MTs pada materi luas bangun datar dan menghubungi guru matematika di sekolah. Hasil analisis adalah materi luas diberikan di kelas VII.Hasil koordinasi dengan guru dijadwalkan pertemuan dengan seorang siswa, sekelompok siswa, dan siswa kelas VII. Kemudian peneliti mendesain materi (prototyping), hasil desain ini nanti akan dievaluasi. Tahap selanjutnya adalah formatif Study, pertama melakukan Self Evaluation pada hasil desain, Evaluasi dilakukan untuk mengetahui perkembangan dan keberhasilan desain. Semua perhatian terfokus pada kejelasan isi dan kebermaknaan gambar dan animasi serta kesesuaian konteks yang dapat membimbing siswa untuk memahami konsep luas.Hasil Self Evaluation iniadalahprototipepertama.Berikutdita mpilkanhasilprototipepertama.

\section{Media Pembelajaran Luas Persegi Panjang}

Media pembelajaran luas persegi panjang merupakan bahan demonstrasi untuk menjelaskan konsep luas persegi panjang. Siswa diharapkan mampu memahami dalam menentukan luas persegi panjang dengan menghitung jumlah persegi kecil sehingga menemukan rumus luas persegi panjang adalah panjang kali lebar. Media pembelajaran luas persegi panjang dapat dilihat pada gambar 1 berikut.

\section{LUAS PERSEGI PANJANG}

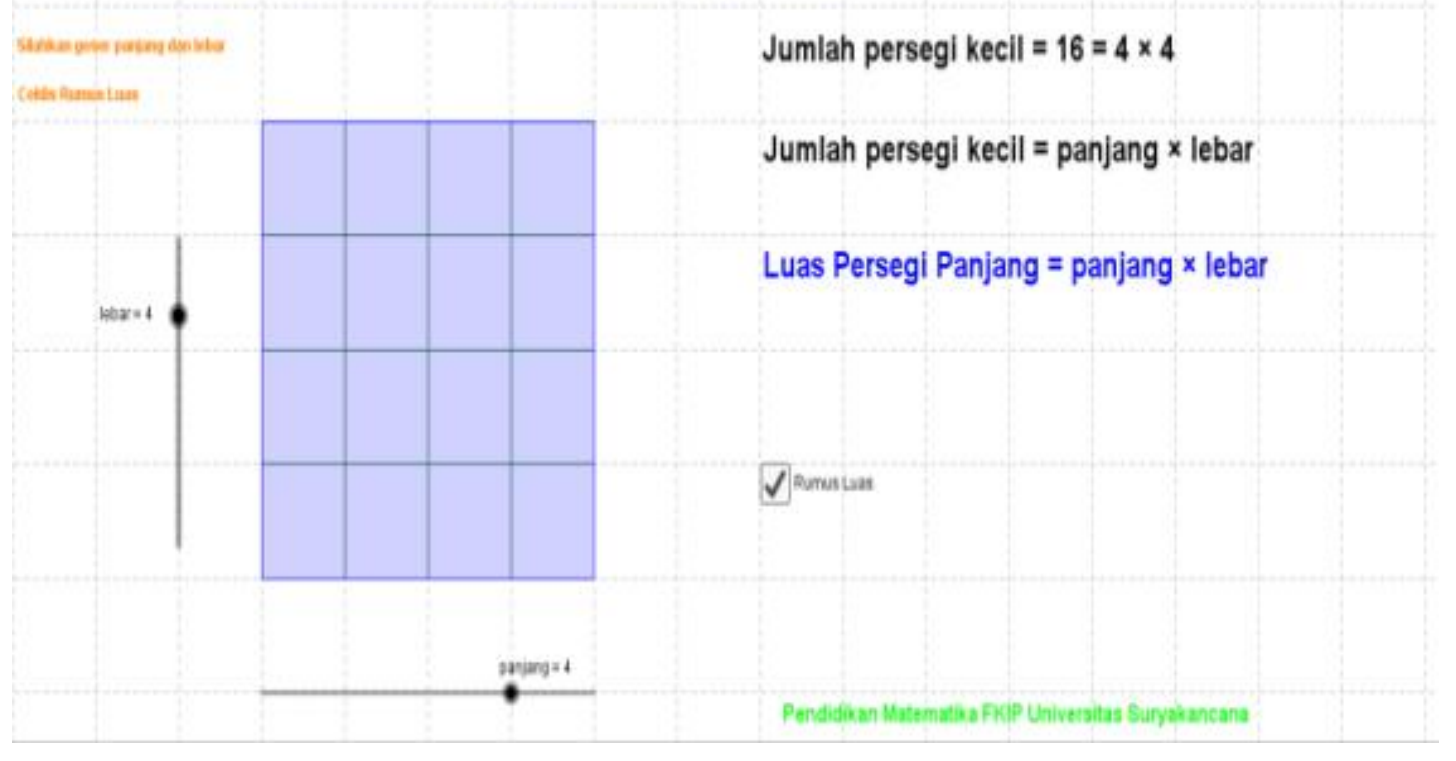

Gambar 1.

Media pembelajaran Luas Persegi Panjang 
Media Pembelajaran Luas Segitiga Media pembelajaran luas segitiga merupakan bahan demonstrasi untuk menjelaskan konsep luas segitiga. Siswa diharapkan mampu memahami dalam menentukan luas segitiga dengan merubah menjadi bentuk persegi panjang sehingga menemukan bahwa rumus luas segitiga adalah $1 / 2$ kali alas kali tinggi. Media pembelajaran luas segitiga dapat dilihat pada gambar 2 berikut.

\section{Luas Segitiga}

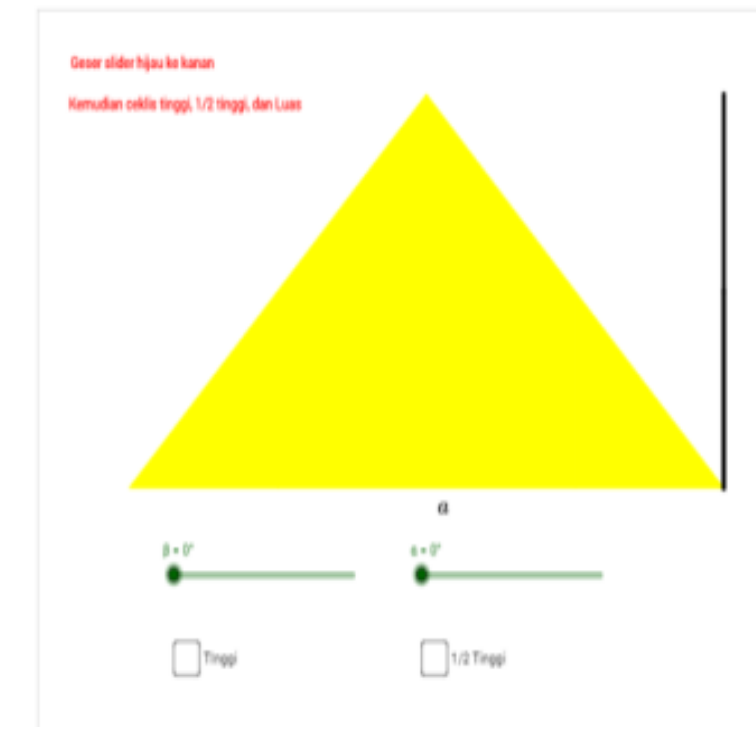

Luas Segitiga

Geser siter ląw ke kanm

Luas Segitiga

Kemuan ceth trox 12 tingo, dentues

$\checkmark$ was

$L=\frac{1}{2} \times a \times t$

$t$
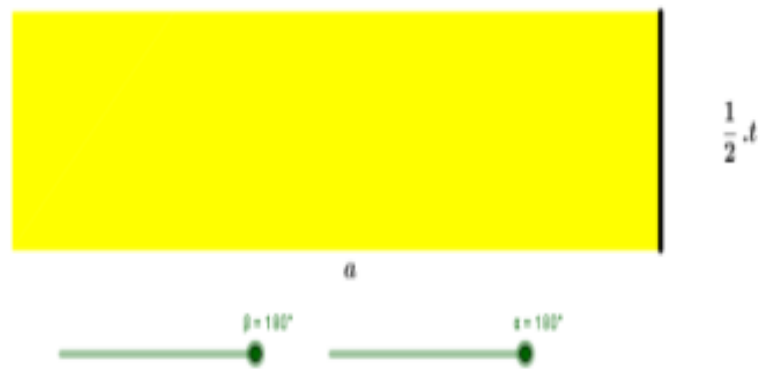

$\nabla^{\operatorname{tiney}} \quad \nabla^{12 \text { Tino }}$

Gambar 2.

Media pembelajaran Luas Segitiga 
Media Pembelajaran Luas dalam menentukan luas jajargenjang Jajargenjang dengan merubah menjadi bentuk persegi panjang sehingga menemukan Media pembelajaran luas jajargenjang merupakan bahan demonstrasi untuk menjelaskan konsep luas jajargenjang. Siswa diharapkan mampu memahami bahwa luas jajargenjang adalah alas kali tinggi. Media pembelajaran luas jajargenjang dapat dilihat pada gambar 3 berikut

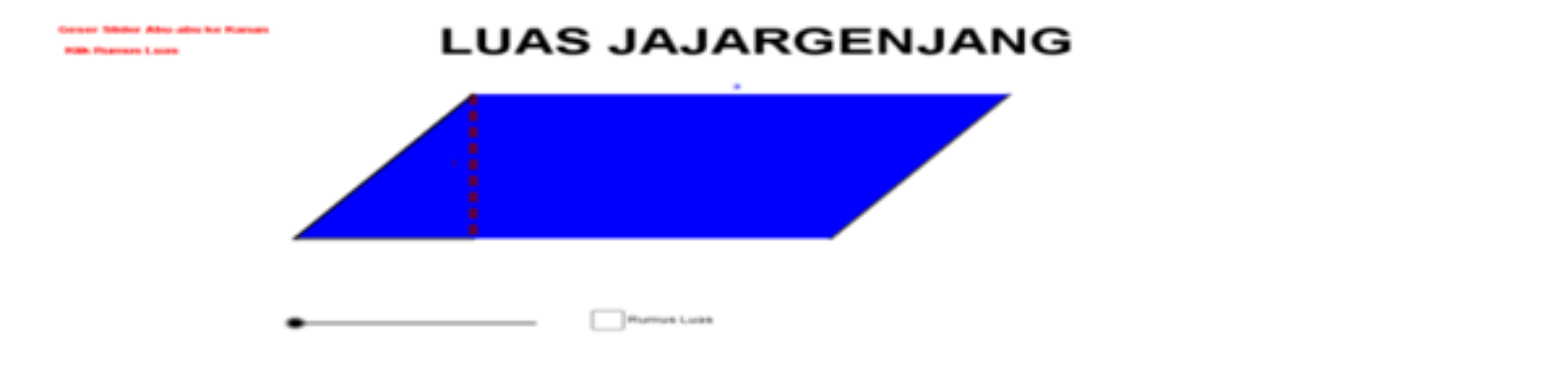

LUAS JAJARGENJANG

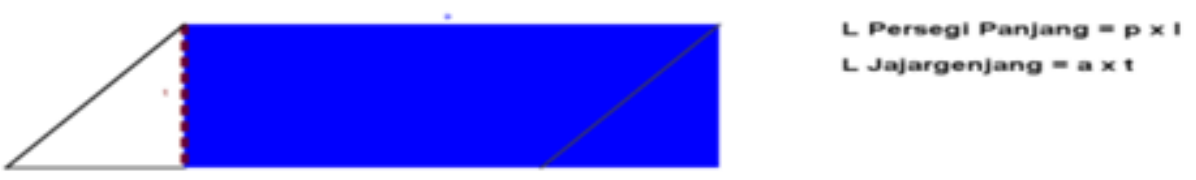

Gambar 3.

Media pembelajaran Luas Jajargenjang

Media Pembelajaran Luas Layanglayang

Media pembelajaran luas layang-layang merupakan bahan demonstrasi untuk menjelaskan konsep luas layang-layang. Siswa diharapkan mampu memahami dalam menentukan luas layang-layang dengan merubah menjadi dua buah segitiga sehingga menemukan bahwa luas layang-layang adalah setengah kali diagonal satu kali diagonal dua. Media pembelajaran luas layanglayang dapat dilihat pada gambar 4 berikut 


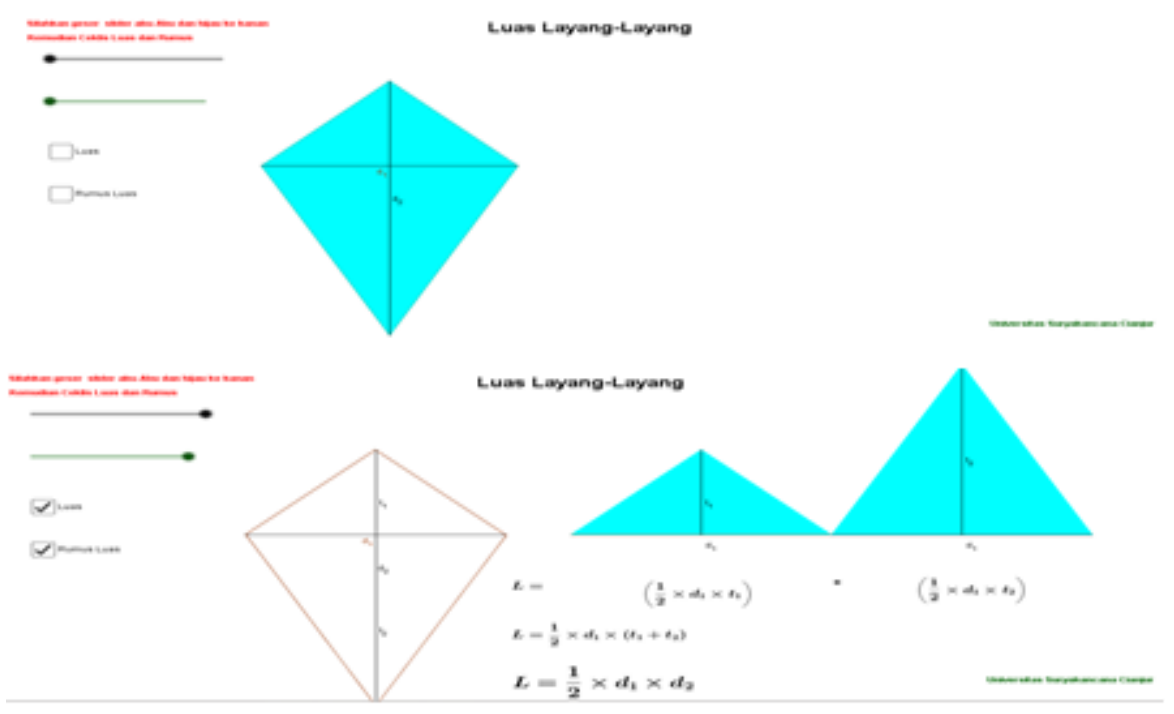

\section{Gambar 4.}

Media pembelajaran Luas Layang-layang

\section{Media Pembelajaran Luas}

\section{Trapesium}

Media pembelajaran luas trapesium merupakan bahan demonstrasi untuk menjelaskan konsep luas trapesium. Siswa diharapkan mampu memahami dalam menentukan luas trapesium dengan merubah menjadi dua buah segitiga sehingga menemukan bahwa luas trapesium adalah setengah kali jumlah sisi sejajar kali tinggi. Media pembelajaran luas trapesium dapat dilihat pada gambar 5 berikut.

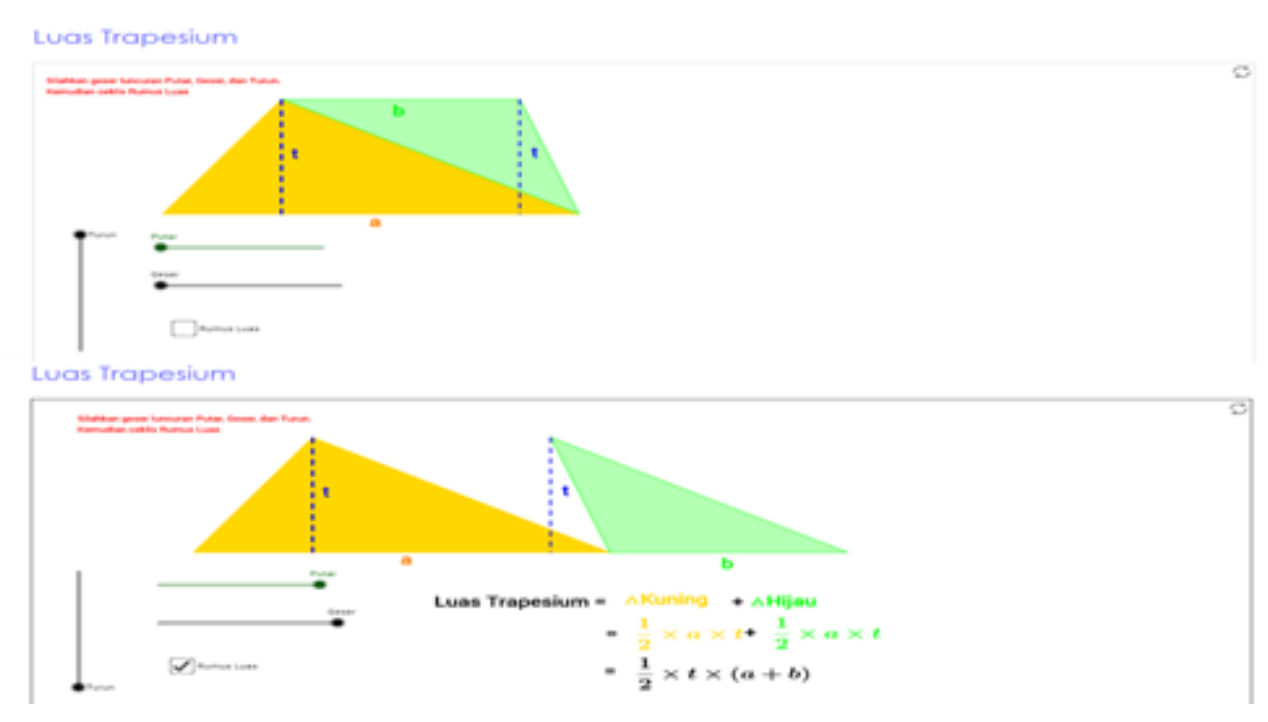

Gambar 5.

Media pembelajaran Luas Trapesium 
Media Pembelajaran Luas

\section{Lingakaran}

Media pembelajaran luas lingkaran merupakan bahan demonstrasi untuk menjelaskan konsep luas lingkaran. Siswa diharapkan mampu memahami dalam menentukan luas lingkaran dengan merubah menjadi persegi sehingga menemukan bahwa luas lingkaran adalah phi kali kuadrat jarijari. Media pembelajaran luas lingkaran dapat dilihat pada gambar 6 . Berikut.

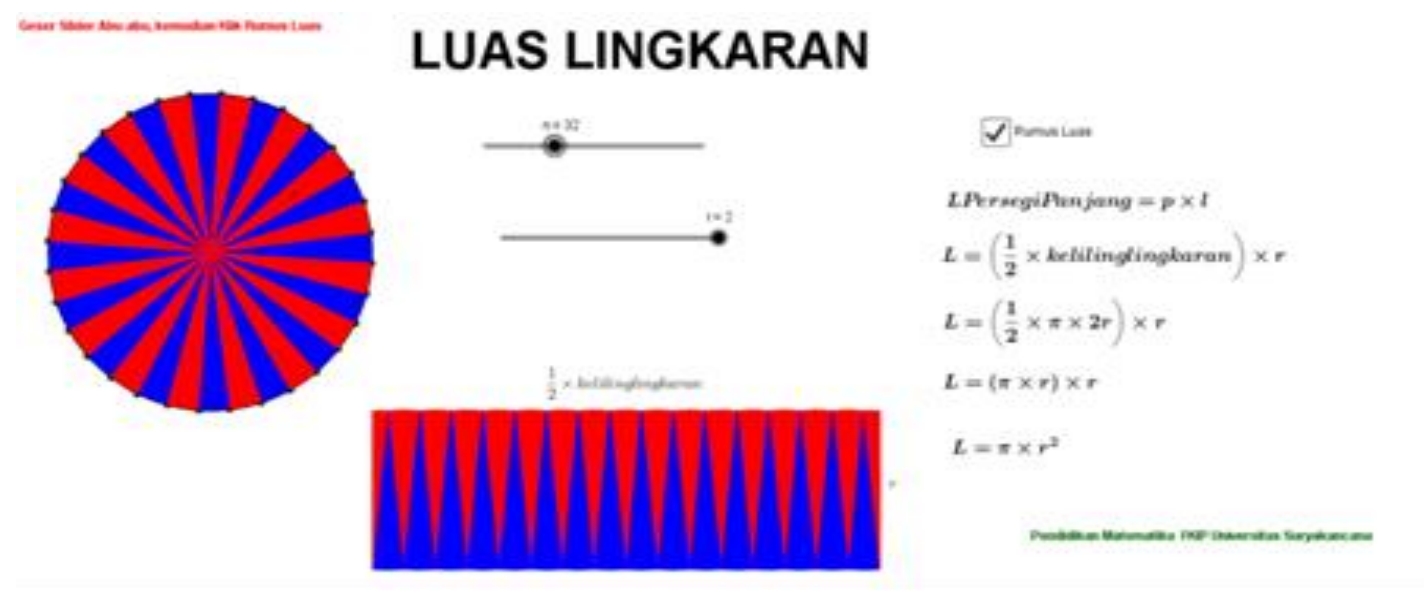

Gambar 6.

\section{Media pembelajaran Luas Lingkaran}

\section{Validasi Praktisi}

Selanjutnya media pembelajaran tersebut dikonsultasikan dengan praktisi. Praktisi adalah tiga orang guru SMP/ MTs. Adapun saran dan masukan dari praktisi sebagai berikut.

Tabel 1.

Saran dan Masukan Praktisi

\begin{tabular}{|l|l|l|}
\hline No & \multicolumn{1}{|c|}{ Saran dan Masukan } & \multicolumn{1}{c|}{ Perbaikan } \\
\hline 1. & $\begin{array}{l}\text { Media pembelajaran luas segitiga ketika } \\
\text { terjadi perubahan dari bentuk segitiga ke } \\
\text { persegi panjang keterangan tinggi belum } \\
\text { hilang }\end{array}$ & $\begin{array}{l}\text { keterangan tinggi dihilangkan ketika terjadi } \\
\text { perubahan dari bentuk segitiga ke persegi } \\
\text { panjang }\end{array}$ \\
\hline 2. & $\begin{array}{l}\text { Instruksi pada media pembelajaran segitiga } \\
\text { sebaiknya dirubah dari kemudian ceklis } \\
\text { tinggi dan ceklis 1/2 dan luas menjadi } \\
\text { kemudian hilangkan ceklis tinggi (tinggi } \\
\text { sudah diceklis diawal), ceklis setengah tingi } \\
\text { dan luas disesuaikan dengan saran nomor 1. } \\
\text { dirubah dari kemudian ceklis tinggi dan } \\
\text { ceklis 1/2 dan luas menjadi kemudian } \\
\text { hilangkan ceklis tinggi (tinggi sudah diceklis } \\
\text { diawal), ceklis setengah tingi dan luas }\end{array}$ \\
\hline 3. & $\begin{array}{l}\text { Instruksi pada media pembelajaran trapesium } \\
\text { sebaiknya dirubah dari silahkan geser } \\
\text { luncuran putar, geser dan turun menjadi } \\
\text { turun, putar, dan geser karena segitiga hijau } \\
\text { pada pergerakannya tidak terlihat. }\end{array}$ & $\begin{array}{l}\text { Instruksi pada media pembelajaran trapesium } \\
\text { sebaiknya dirubah dari silahkan geser } \\
\text { luncuran putar, geser dan turun menjadi } \\
\text { turun, putar, dan geser }\end{array}$ \\
\hline
\end{tabular}




\begin{tabular}{llll}
\multicolumn{2}{c}{ Berdasarkan saran dan } & terjadi perubahan dari bentuk segitiga \\
masukan dari teman sejawat dan & ke persegi panjang dan Instruksi pada \\
praktisi, dilakukan perbaikan untuk & media pembelajaran segitiga dirubah \\
media pembelajaran segitiga dan & dari kemudian ceklis tinggi dan ceklis \\
trapesium, sedangkan media & $\begin{array}{l}1 / 2 \text { dan luas menjadi kemudian } \\
\text { pembelajaran yang lainnya tetap. }\end{array}$ hilangkan ceklis tinggi (tinggi sudah \\
Adapun perbaikan media & diceklis diawal), ceklis setengah tingi \\
pembelajaran segitiga dan trapesium & dan luas. Media pembelajaran hasil \\
sebagai berikut & revisi ini sebagai prototipe kedua. \\
Media Pembelajaran Segitiga & Media pembelajaran luas segitiga \\
Perbaikan dan revisi media & setelah direvisi dapat dilihat pada \\
pembelajaran luas segitiga, yaitu & gambar 7 berikut.
\end{tabular}

keterangan tinggi dihilangkan ketika

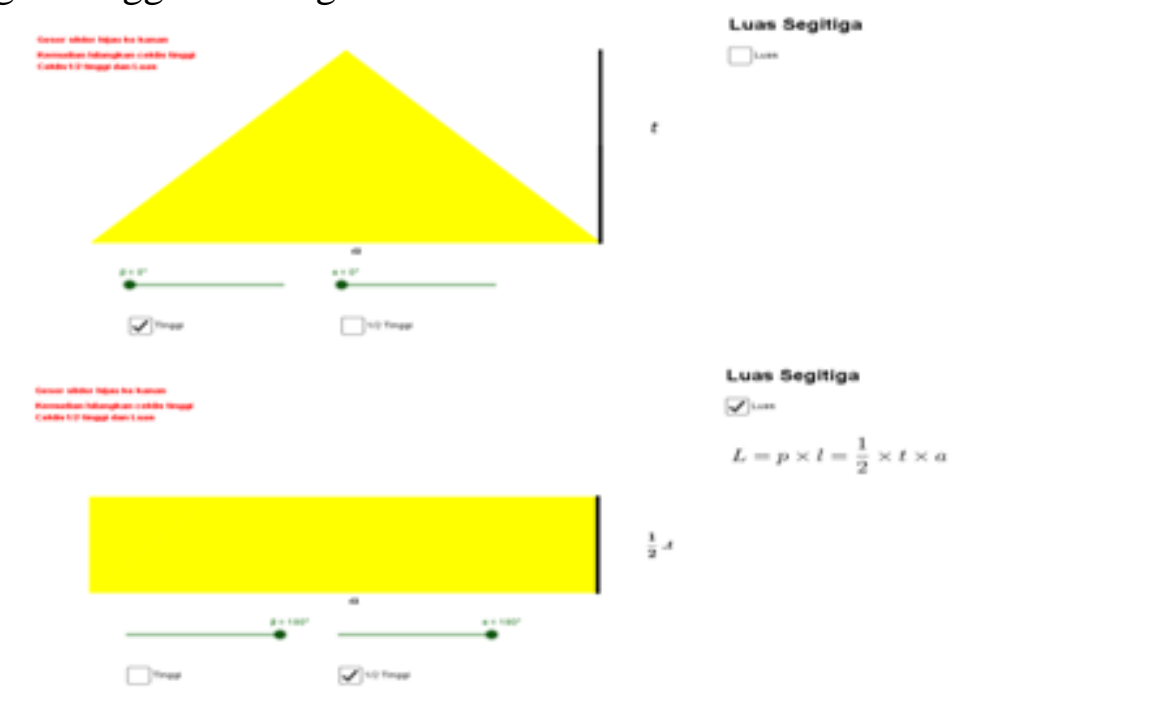

\section{Gambar 7.}

\section{Hasil Revisi Media pembelajaran Segitiga}

\section{Media Pembelajaran Trapesium}

Perbaikan dan revisi media pembelajaran luas trapesium, yaitu Instruksi pada media pembelajaran trapesium sebaiknya dirubah dari silahkan geser luncuran putar, geser dan turun menjadi turun, putar, dan geser. Media pembelajaran hasil revisi ini sebagai prototipe kedua. Media pembelajaran luas trapesium setelah direvisi dapat dilihat pada gambar 8 berikut. 


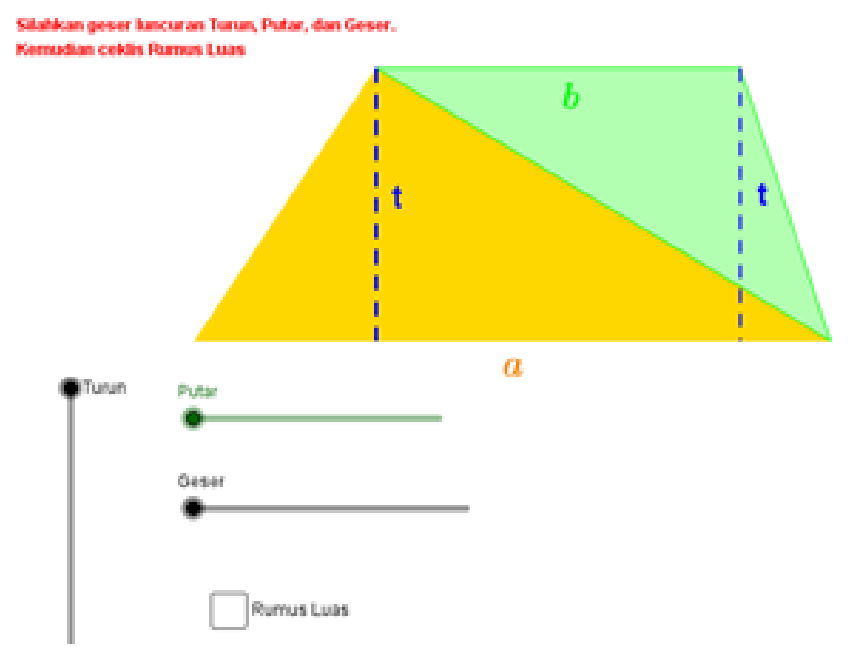

Gambar 8.

Media pembelajaran Trapesium Hasil Revisi

\section{Uji Lapangan}

Selanjutnya media pembelajaran setelah perbaikan berdasarkan saran dan masukan dari praktisi, media pembelajaran luas tersebut diujicobakan ke pada siswa dalam pembelajaran di kelas. Media pembelajaran ini digunakan sebagai bahan demontrasi untuk menjelaskan luas persegi panjang, segitiga, layanglayang, trapesium, dan segitiga. Setelah pembelajaran di kelas, para siswa diberikan angket untuk mengetahui respon siswa. Adapun hasil angket siswa sebagai berikut:.

Tabel 2.

Hasil Angket

\begin{tabular}{|c|c|c|c|c|c|}
\hline NO & Pernyataan & SS & $\mathbf{S}$ & TS & STS \\
\hline 1 & Saya suka belajar dengan menggunakan media computer & $24 \%$ & $76 \%$ & $0 \%$ & $0 \%$ \\
\hline 2 & $\begin{array}{l}\text { Saya suka belajar dengan menggunakan perangkat lunak } \\
\text { GeoGebra }\end{array}$ & $45 \%$ & $55 \%$ & $0 \%$ & $0 \%$ \\
\hline 3 & $\begin{array}{l}\text { Saya memahami konsep luas dengan belajar menggunakan } \\
\text { media pembelajaran dengan perangkat lunak GeoGebra }\end{array}$ & $18 \%$ & $82 \%$ & $0 \%$ & $0 \%$ \\
\hline 4 & Gambar membuat saya kesulitan memahami konsep luas & $0 \%$ & $3 \%$ & $73 \%$ & $24 \%$ \\
\hline 5 & $\begin{array}{l}\text { Tulisan atau penjelasan yang disajikan membantu saya } \\
\text { memahami konsep luas }\end{array}$ & $27 \%$ & $61 \%$ & $9 \%$ & $3 \%$ \\
\hline 6 & $\begin{array}{l}\text { Penjelasan atau tulisan membuat saya kesulitan memahami } \\
\text { konsep luas }\end{array}$ & $0 \%$ & $15 \%$ & $55 \%$ & $12 \%$ \\
\hline 7 & $\begin{array}{l}\text { Warna gambar dan tulisan membantu saya memahami konsep } \\
\qquad \text { luas }\end{array}$ & $18 \%$ & $82 \%$ & $0 \%$ & $0 \%$ \\
\hline 8 & $\begin{array}{l}\text { Saya kesulitan memahami konsep luas dengan pembelajaran } \\
\text { menggunakan media pembelajaran dengan menggunakan }\end{array}$ & $0 \%$ & $3 \%$ & $70 \%$ & $27 \%$ \\
\hline
\end{tabular}




\begin{tabular}{|c|c|c|c|c|c|}
\hline NO & Pernyataan & SS & S & TS & STS \\
\hline & perangkat lunak GeoGebra & & & \\
\hline 9 & $\begin{array}{c}\text { Gambar yang disajikan mendukung pemahaman saya mengenai } \\
\text { konsep luas }\end{array}$ & $27 \%$ & $73 \%$ & $0 \%$ & $0 \%$ \\
\hline 10 & Animasi membuat saya kesulitan memahami konsep luas & $3 \%$ & $9 \%$ & $67 \%$ & $24 \%$ \\
\hline 11 & $\begin{array}{c}\text { Animasi yang disajikan mendukung pemahaman saya mengenai } \\
\text { konsep luas }\end{array}$ & $18 \%$ & $79 \%$ & $3 \%$ & $0 \%$ \\
\hline 12 & Warna gambar dan tulisan tidak berhubungan sama sekali & $0 \%$ & $9 \%$ & $58 \%$ & $33 \%$ \\
\hline
\end{tabular}

Berdasarkan tabel diketahui bahwa $24 \%$ sangat setuju dan $76 \%$ siswa setuju bahwa mereka menyukai belajar dengan media komputer. $45 \%$ sangat setuju dan $55 \%$ setuju bahwa mereka menyukai belajar dengan perangkat lunak Geogebra. 18\% sangat setuju dan $82 \%$ setuju bahwa mereka memahami konsep luas dengan belajar menggunakan media pembelajaran dengan perangkat lunak GeoGebra. 27\% siswa sangat setuju dan $61 \%$ siswa setuju bahwa tulisan atau penjelasan yang disajikan membantu siswa memahami konsep luas. $27 \%$ siswa sangat setuju dan $27 \%$ siswa setuju bahwa warna gambar dan tulisan membantu saya memahami konsep luas. $18 \%$ siswa sangat setuju dan $79 \%$ siswa setuju bahwa animasi yang disajikan mendukung pemahaman saya mengenai konsep luas. Respon siswa hampir semua sangat setuju dan setuju bahwa mereka menyukai belajar dengan perangkat lunak Geogebra dan media pembelajaran membantu mereka dalam memahami konsep luas. Hal tersebut juga dapat dilihat dari pernyataan negatif bahwa hampir semua tidak setuju dan sangat tidak setuju.

Selanjutnya ditanyakan kepada siswa media pembelajaran mana yang paling membantu mereka dalam memahami konsep luas dan media pembelajaran mana yang paling sulit dipahami. Berikut hasil dapat dilihat di tabel 3. dan tabel 4.

Tabel 3.

Media pembelajaran yang Paling Membantu Mereka dalam Memahami

Konsep Luas

\begin{tabular}{|c|c|c|}
\hline $\begin{array}{c}\text { Media } \\
\text { pembelajaran Luas }\end{array}$ & $\begin{array}{c}\text { Banyak } \\
\text { Siswa }\end{array}$ & Persentase \\
\hline Persegi Panjang & 29 & $88 \%$ \\
\hline Segitiga & 11 & $33 \%$ \\
\hline Jajargenjang & 5 & $15 \%$ \\
\hline Layang-layang & 5 & $15 \%$ \\
\hline Trapesium & 6 & $18 \%$ \\
\hline Lingkaran & 5 & $15 \%$ \\
\hline
\end{tabular}


Berdasarkan tabel 3. diketahui bahwa Media pembelajaran Luas Persegi Panjang adalah media pembelajaran yang paling membantu mereka dalam memahami konsep luas yaitu $88 \%$ siswa. Sedangkan Media pembelajaran
Luas Segitiga 33\%, Media pembelajaran Luas Trapesium 18\%, dan Media pembelajaran Luas Jajargenjang, Layang-layang, dan Lingkaran $15 \%$.

Tabel4.

Media pembelajaran yang Paling Sulit dalam Memahami Konsep Luas

\begin{tabular}{|c|c|c|}
\hline $\begin{array}{c}\text { Media } \\
\text { pembelajaran } \\
\text { Luas }\end{array}$ & $\begin{array}{c}\text { Banyak } \\
\text { Siswa }\end{array}$ & Persentase \\
\hline Persegi Panjang & 0 & $0 \%$ \\
\hline Segitiga & 0 & $0 \%$ \\
\hline Jajargenjang & 4 & $12 \%$ \\
\hline Layang-layang & 9 & $27 \%$ \\
\hline Trapesium & 7 & $21 \%$ \\
\hline Lingkaran & 16 & $48 \%$ \\
\hline
\end{tabular}

Berdasarkan tabel4. diketahui bahwa Media pembelajaran Lingkaran adalah media pembelajaran yang paling sulit dalam memahami konsep luas yaitu $48 \%$ siswa. Sedangkan Media pembelajaran Luas Laynglayang 27\%, Media pembelajaran Luas Trapesium 21\% dan Media pembelajaran Jajargenjang $12 \%$. Media pembelajaran Luas Persegi Panjang dan Media pembelajaran Luas Segitiga $0 \%$.

Hampir semua siswa berpendapat bahwa Media pembelajaran Luas Persegi Panjang merupakan media pembelajaran yang paling membantu mereka memahami konsep luas. Sedangkan hampir setengahnya siswa menyatakan bahwa Media pembelajaran Luas Lingkaran paling sulit dipahami.

\section{KESIMPULAN DAN SARAN}

\section{Kesimpulan}

Berdasarkan pembahasan sebelumnya, maka dapat disimpulkan sebagai berikut:

1. Hasil pengembangan media pembelajaran luas di MTs Kab. Bandung valid berdasarkan isi, bahasa, dan kesesuaian konteks yang digunakan dan praktis berdasarkan kemudahan digunakan siswa.

2. Hasil uji coba pengembangan yang media pembelajaran luas yang diberikan di MTs Kab. Mempunyai efek yang potensial, yaitu:
a. Siswa suka belajar dengan media komputer
b. Siswa suka belajar dengan perangkat lunak Geogebra
c. Media pembelajaran luas dengan perangkat lunak Geogebra membantu siswa memahami konsep luas
d. Media pembelajaran luas persegi panjang paling


membantu siswa memahami konsep luas

\section{Saran}

Berdasarkan kesimpulan di atas, maka peneliti dapat menyarankan halhal sebagai berikut:

1. Bagi guru matematika dapat menggunakan bahan ajar konsep luas bidang datar berbasis perangkat lunak GeoGebra yang dihasilkan dalam penelitian ini sebagai alternatif dalam menjelaskan konsep luas bangun datar.

2. Bagi siswa dalam belajar menggunakan bahan ajar konsep luas bidang datar berbasis perangkat lunak GeoGebra diharapkan dapat memberikan suasana baru dan meningkatkan pemahaman konsep luas bidang datar.

3. Bagi peneliti, diharapkan supaya dapat mendesain bahan ajar yang lebih baik terutama yang masih sulit dipahami siswa sehingga dapat lebih mudah dipahami siswa.

\section{DAFTAR PUSTAKA}

GeoGebra. (n.d). Diakses 12 September 2014, dari http://www.GeoGebra.org/cms/ in/info.

Hohenwarter, J., Hohenwarter, M. (2013). Introduction to Geogebra Version 4.4. Diakses dari

https://static.geogebra.org/book /intro-en.pdf

Leshin, Pollock \& Reigeluth. (1992). Instructional Design Strategies and Tactics. Englewood Cliffs, NJ: Educational Technology Publication.
Mahmudi, Ali. (2011). Pemanfaatan GeoGebra dalam Pembelajaran Matematika. Diakses dari Universitas Negeri Yogyakarta, Situs Web http://staff.uny.ac.id/sites/defau 1t/files/Makalah\%2017\%20Se mnas\%20LPM\%20UNY\%202 011\%20_Pemanfaatan\%20Geo Gebra\%20dalam\%20Pembelaj aran\%20Matematika_.pdf Nizarwati,N., Hartono, Y., Aisyah, N. (2009). Pengembangan perangkat pembelajaran Berorientasi konstruktivisme untuk Mengajarkan Konsep Perbandingan Trigonometri Siswa Kelas $x$ SMA. Jurnal Pendidikan Matematika, 3(2), 57-72. Diakses dari http://ejournal.unsri.ac.id/index.php/jp $\underline{\mathrm{m} / \text { article/view/328/92 }}$ 
